\title{
THE TAX BENEFIT RULE AND THE LOSS CARRYOVER PROVISIONS OF THE 1954 CODE
}

INCOME tax returns which accurately reflect the net economic gain realized by taxpayers within annual accounting periods permit consistent, administratively workable revenue collection. ${ }^{1}$ Separate tax treatment of each fiscal year's income, however, may unduly burden taxpayers whose gain and loss years are interspersed, ${ }^{2}$ since taxing all the income received in years of net gain

1. "It is the essence of any system of taxation that it should produce revenue ascertainable, and payable to the government, at regular intervals. Only by such a system is it practicable to produce a regular flow of income and apply methods of accounting, assessment, and collection capable of practical operation." Burnet v. Sanford \& Brooks Co., 282 U.S. 359, 365 (1931). Although Burnet's rigid annual approach has been judicially modified, see, e.g., Dobson v. Commissioner, 320 U.S. 489, 504, 506-07 (1943), its thrust coincides with the emphasis on annual accounting evident in the Internal Revenue Code, see, e.g.; INT. REv. CODE OF 1954, § 451 ("The amount of any item of gross income shall be included in the gross income for the taxable year in which received by the taxpayer ..."). Burnet's assertion that income taxation operates on a strictly annual basis has been widely followed. See, e.g., Security Flour Mills Co. v. Commissioner, 321 U.S. 281 (1944); Mim. 6444, 1949-2 Cum. Bulz. 11, 12.

2. "Annual assessment of income tax does not harm the firm with a consistent record of profits, but the firm whose income record is interspersed with losses suffers discrimination." Beck, Carryover of Business Lo'sses, 6 NAT'L TAX J. 69, 70 (1953). See, generally, Vickrey, Agenda for Progressive Taxatton 164-68 (1947) (critically analyzing suggested rationalizations for heavier taxation of fluctuating income); Dickerson, Avcraging Income for Tax Purposes, J. Accountancy, May 1958, p. 27; Jornt Commitee on taE EcoNomic Report, Federal Tax Policy for Economic Growtr and Stability, 84th Cong., 1st Sess. 135 (1955) ; Holt, Averaging of Income for Tax Purposes: Equity and FiscalPolicy Considerations, 2 NAT'L TAX J. 349 (1949) (suggesting three major weaknesses in the federal income tax system-the heavier tax borne by a fluctuating income stream, the interaction between fluctuating incomes and fluctuating tax rates, and the political difficulty in making countercyclical changes in tax rates); Steger, On the Theoretical Equity of an Averaging Concept for Income Tax Purposes, 13 TAX L. Rev. 211, 223-24 (1958).

Despite similarities, differences exist between averaging fluctuating income and offsetting the losses of one year against the income of another year. Fluctuating positive income is affected adversely only by progressive tax rates, while fluctuating positive and negative income involves not only progressive tax rates but also taxation of amounts representing recoupment of expenditures. See note 3 infra. Accordingly, ameliorated tax treatment for the latter type of income pattern is, in the individual case at least, highly desirable.

The 1954 Code contains several provisions mitigating certain of the harsh effects which strict annualization and progressive tax rates may have on fluctuating income. See INT. REv. CODE OF 1954, § 1301, which allows taxpayers rendering personal services for thirtysix months or more and receiving $80 \%$ of the compensation for the services in a single taxable year to treat the compensation as ratably received over the period during which it was earned; id. $\$ 1302$, which authorizes certain inventors and artists to treat income from long-term projects as if received ratably during periods of sixty and thirty-six months respectively; id. $\S 1303$, which permits a taxpayer receiving back pay in excess of $15 \%$ of his gross income to include such payment in gross income for the taxable year to which 
without making allowance for intervening losses constitutes a levy on return of capital to the extent of the intervening losses. ${ }^{3}$ To avoid the taxation of amounts representing the recoupment of expenses incurred in the pursuit of profit, the Internal Revenue Code contains devices for adjusting annual tax incidence to the net economic results of multiannual periods. Specifically, provisions for loss carrybacks and carryforwards (both hereinafter referred to as carryovers) permit the net loss of one year to offset income in earlier and later years, and thus serve to prevent tax imposition before recovery of business expenditures. ${ }^{4}$ Alternatively, the "tax benefit rule" may allow returns of capital to escape taxation by excluding from gross income amounts received in respect of certain items which were previously deducted without reducing $\operatorname{tax}$ liability in any year. ${ }^{5}$

By facilitating tax-free capital recoveries, carryovers and the tax benefit rule implement a basic policy of legislative self-restraint ${ }^{6}$ which, though not required by the constitutional power to tax gross income, ${ }^{7}$ would avoid levies on the recoupment of expenditures incurred for profit. ${ }^{8}$ Nevertheless, departures from the standard of strict annual accounting are often granted grudg-

it is attributable; $i d . \S 1304$, which provides that if a compensatory damage award is received or accrued during a taxable year as a result of a civil action for patent infringement, the award may be taxed as if ratably received during each month of the infringement. See also H.R. REp. No. 1357, 84th Cong., 1st Sess. 2 (1955) (explaining $§ 1304$ ).

3. "In the absence of the loss offsets, the business entity whose net income becomes negative in some periods is not permitted to deduct all the expenses of earning income. To this extent, the tax on net income becomes a tax on capital. The owners of such a firm are discriminated against, because higher taxes are levied on their income than on the income of businesses with stable income." U.S. Treasury Departarent and Jornt Consmittee on Internal Revenue Taxation, Business Loss Offsets 2 (1947), reproduced in Brttker, Federal Income Estate and Gift Taxation 713 (1955). "The use of a single year as the taxable period, without providing for the offset of losses against profits, may convert the income tax into a capital levy. The reason is that the firm whose net income becomes negative is deprived of the right to deduct all the expenses of earning income." Beck, supra note 2, at 70. In contrast, the firm with income each year sufficient to absorb business expenditures attributable to that year can take full advantage of those sections of the Code, such as $\$ \$ 162$ and 163 , which provide for the deduction of items like business expenses and interest "paid or incurred during the taxable year." See INT. REv. CoDE of 1954, \$\$ 161-67.

If a taxpayer invests capital or incurs capital expenses, he realizes no "income" when that capital is returned to him. See Henderson, Introduction to Incone Taxation $\S$ 32 (2d ed. 1949). Hence, federal income taxation has avoided levies on capital recovery. See, e.g., Burnet v. Logan, 283 U.S. 404 (1931) (stock sold for flat sum plus contingent annual payments held not to constitute income until full basis of stock recovered).

4. For the net operating loss carryover provision, discussed notes 9-12 infra and accompanying text, see INT. REv. CoDE of 1954, § 172(b), quoted note 9 infra. The Code also allows carryovers for capital losses. Id. $\$ 1212$, quoted note 20 infra.

5. Id. $\$ 111$, quoted note 26 infra; see text at notes 23-28 infra.

6. See HeNDERSON, op. cit. supra note 3 , at $\$ 32$.

7. Congressional power to tax gross income rests on U.S. Const. amend XVI. For discussion of the limits on this power, see MAGILI, TAXABLE INCONE 347-54 (rev. ed. 1945) (collecting cases).

8. See text at notes $26-33$ infra. 
ingly, and taxpayers may not fully exploit the principle underlying carryovers and the tax benefit rule. This Comment will evaluate the effectiveness and interaction of the two devices in securing tax-free capital recovery, and will suggest the course which their future development should follow.

\section{Net Operating Loss Carryovers}

The principal relief from the rigors of annual accounting is provided by section 172 of the 1954 Code, which allows a "net operating loss" incurred in one year to be offset against income of the previous two years and the following five. ${ }^{9}$ If carryovers from two or more years are used in a given year, they are applied against income in chronological order. ${ }^{10}$ Generally speaking, net operating loss for a given year is computed in the same manner as taxable income. ${ }^{11}$ To avoid its being counted twice or being extended beyond the statutory period, a net operating loss from another year may be deducted only in computing current taxable income and not in computing current net operating loss. ${ }^{12}$

9. INT. Rev. CODE oF 1954, $\$ 172$ (a)-(b) provide:

"(a) ... There shall be allowed as a deduction for the taxable year an amount equal to the aggregate of (1) the net operating loss carryovers to such year, plus (2) the net operating loss carrybacks to such year. For purposes of this subtitle, the term 'net operating loss deduction' means the deduction allowed by this subsection. 1953, shall be-

"(b) (1) ... A net operating loss for any taxable year ending after December 31,

(A) a net operating loss carryback to each of the 2 taxable years preceding the taxable year of such loss, and

(B) a net operating loss carryover to each of the 5 taxable years following the taxable year of such loss."

For a history of operating loss carryovers, see 5 MERTENS, FEDERAL Inconse TAXATION $\S 29.01$ (1956) (hereinafter cited as MERTENS).

10. Id. $\S 29.02 \mathrm{~d}$.

11. "For purposes of this section, the term 'net operating loss' means (for any taxable year ending after December 31,1953 ) the excess of the deductions allowed by this chapter over the gross income. Such excess shall be computed with the modifications specified in subsection (d)." INT. REv. CoDE of 1954, § 172(c).

Minor exceptions for corporate taxpayers are as follows:

(5) ... No deduction shall be allowed under section 242 (relating to partially tax-exempt interest) or under section 922 (relating to Western Hemisphere trade corporations).

(6) ... The deductions allowed by sections 243 [granting corporation deduction of $85 \%$ of dividends received from taxable domestic corporations] . . . 244 (relating to dividends received on certain preferred stock of public utilities), and 245 (relating to dividends received from certain foreign corporations) shall be computed without regard to section 246 (b) [limiting the aggregate amount of deductions allowed by sections 243,244 and 245 to $85 \%$ of taxable income computed without regard to those sections or to net operating loss] ... and the deductions allowed by section 247 (relating to dividends paid on certain preferred stock of public utilities) shall be computed without regard to subsection (a) (1) (B) of such section." Id. \$§ 172 (d) (5)-(6).

12. $I d . \S 172(\mathrm{~d})(1)$. 
Within this framework, the only important restriction on a corporation's loss carryover is the statutory period. Section 172 carryovers for individuals, however, exclude personal exemptions, deductions attributable to net capital loss and the deduction of one half of net capital gain authorized under section 1202.13 More important, in computing carryover from another year, nonbusiness deductions in that year-other than those for casualty losses-are recognized only to the extent of concurrent nonbusiness gain. ${ }^{14}$

Section 172 also limits the amount of net operating loss available for carryover beyond the earliest of the seven statutory years. Although the entire loss may be used to offset taxable income in that year, ${ }^{15}$ any loss which is still

13. "(d) ....

(2) ... In the case of a taxpayer other than a corporation-

(A) the amount deductible on account of losses from sales or exchanges of capital assets shall not exceed the amount includible on account of gains from sales or exchanges of capital assets; and

(B) the deduction for long-term capital gains provided by section 1202 shall not be allowed.

(3) ... No deduction shall be allowed under section 151 (relating to personal exemptions). No deduction in lieu of any such deduction shall be allowed.

(4) ... In the case of a taxpayer other than a corporation, the deductions allowable by this chapter which are not attributable to a taxpayer's trade or business shall be allowed only to the extent of the amount of the gross income not derived from such trade or business. For purposes of the preceding sentence-

(A) Any gain or loss from the sale or other disposition of-

(i) property, used in the trade or business, of a character which is subject to the allowance for depreciation provided in section 167 , or

(ii) real property used in the trade or business, shall be treated as attributable to the trade or business;

(B) the modifications specified in paragraphs (1), (2) (B), and (3), shall be taken into account; and

(C) any deductions allowable under section 165 (c) (3) (relating to casualty losses) shall not be taken into account." Id. $\S \S 172$ (d) (2)-(4).

14. Id. $\S 172(\mathrm{~d})(4)$, quoted note 13 supra.

15. "Except as provided in subsection (f) [relating to taxable years falling in 195354], the entire amount of the net operating loss for any taxable year (hereinafter in this section referred to as the 'loss year') shall be carried to the earliest of the 7 taxable years to which ... such loss may be carried. The portion of such loss which shall be carried to each of the other 6 taxable years shall be the excess, if any, of the amount of such loss over the sum of the taxable income for each of the prior taxable years to which such loss may be carried. For purposes of the preceding sentence, the taxable income for any such prior taxable year shall be computed-

(A) [with modifications (2), (3), and (5) of subsection (d), quoted note 13 supra] $\ldots$ and

(B) by determining the amount of the net operating loss deduction without regard to the net operating loss for the loss year or for any taxable year thereafter, and the taxable income so computed shall not be considered to be less than zero." Id. § 172 (b) (2). 
unused-that is, unreduced by the taxable income of the initial year-may not be carried to the succeeding years until it is further diminished by certain disfavored deductions of the initial year. ${ }^{16}$ This same process of loss diminution recurs in each of the subsequent years to which the loss is carried. Thus, corporate carryover is diminished by previous deductions for partially tax-exempt interest and for Western Hemisphere trade corporation benefits. ${ }^{17}$ And noncorporate carryovers are reduced by the personal exemption, the amount of net capital loss used to offset ordinary income, and section 1202 deductions. ${ }^{18}$

A further section 172 restriction denies application of the carryover privilege to an excess of capital losses over capital gains. ${ }^{19}$ Governed exclusively by section 1212, this excess is treated as a short-term capital loss in each of five succeeding years, subject to the same restrictions placed on the deductibility of capital losses in the year of realization. ${ }^{20}$ As a result, capital loss and capital loss carryover may only be used to offset the capital gain of a corporation or the capital gain plus $\$ 1000$ of ordinary income reported by a noncorporate taxpayer. ${ }^{21}$ And the carryover, inapplicable unless current capital losses have been deducted, may not create a new net capital loss extending the carryover period. ${ }^{22}$

\section{TAX Benefit Rule}

Normally, subsequent restoration of losses or expenses which have been deducted represents income. ${ }^{23}$ Since no economic gain results from the restoration, imposing a tax on the recovery is justified only because of the previous deduction. ${ }^{24}$ In a year of net loss, however, the taxpayer will have had insufficient income against which to apply all available deductions. Therefore,

16. See Ibid.; see also note 13 supra.

17. INT. Rev. CoDE of 1954, §§ 172(b) (2) (A), (d) (5), quoted notes 11, 15 supra.

18. Id. $\S \S 172(\mathrm{~b})(2)$, (d) (2)-(3), quoted notes 13,15 supra.

19. Id. $\S 172$ (d) (2) (A), quoted note 13 supra (noncorporate taxpayers); id., $\S \S$ 172 (c), quoted note 11 supra, and 1211(a) (corporate taxpayers).

20. Id. \$ 1212. The section provides in part that: "If for any taxable year the taxpayer has a net capital loss, the amount thereof shall be a short-term capital loss in each of the 5 succeeding taxable years to the extent that such amount exceeds the total of any net capital gains of any taxable years intervening between the taxable year in which the net capital loss arose and such succeeding taxable year."

21. Id. § 1211 .

22. See id. $\S 1212 ; 3 \mathrm{~B}$ Mertens $\S 22.09$.

23. Union Trust Co. v. Commissioner, 111 F.2d 60 (7th Cir.), cert. denied, 311 U.S. 658 (1940); Helvering v. Jane Holding Corp., 109 F.2d 933, 939-40, 944 (8th Cir.), cert. denied, 310 U.S. 653 (1940); Houbigant, Inc., 31 B.T.A. 954 (1934), aff'd per curiam, 80 F.2d 1012 (2d Cir.), cert. denied, 298 U.S. 669 (1936).

24. If allowance of a deduction results in a portion of gross income not being taxed, recoupment of the deducted item stands in the place of the gross income which had not been taxed previously and is therefore taxable. National Bank of Commerce v. Commissioner, 115 F.2d 875 (9th Cir. 1940); Estate of James N. Collins, 46 B.T.A. 765 (1942), aff'd sub nom. Dobson v. Commissioner, 320 U.S. 489 (1943). See Plumb, The Taut Benefit Rule Today, 57 HARv. L. REv. 129, 131 n.10 (1943) (suggesting alternative theories for taxation of recoveries). 
if the previous deduction in such a situation did not reduce tax liability, a later recovery with respect to the deduction should not be deemed income. ${ }^{25}$ Accordingly, section 111 of the 1954 Code permits the taxpayer to exclude from income certain restored sums to the extent that deductions or credits previously taken for those sums were of no tax benefit. ${ }^{26}$ Although the language of the section applies solely to recoveries of bad debts, past taxes and penalties for delinquent back taxes, ${ }^{27}$ "section 111 items"-as expanded by administrative interpretation and case law-encompass "most losses, ex-

25. See Hearings Before the Honse Committee on Ways and Means on the Revenue Revision of 1942, 77th Cong., 2d Sess. 80, 87-88 (1942) ; Note, 56 HARv. L. REv. 428, 435 n.46 (1942).

26. "(a) ... Gross income does not include income attributable to the recovery during the taxable year of a bad debt, prior tax, or delinquency amount, to the extent of the amount of the recovery exclusion with respect to such debt, tax, or amount.

“(b) ... For purposes of subsection (a) -

(1) ... The term 'bad debt' means a debt on account of the worthlessness or partial worthlessness of which a deduction was allowed for a prior taxable year.

(2) ... The term 'prior tax' means a tax on account of which a deduction or credit was allowed for a prior taxable year.

(3) ... The term 'delinquency amount' means an amount paid or accrued on account of which a deduction or credit was allowed for a prior taxable year and which is attributable to failure to file return with respect to a tax, or pay a tax, within the time required by the law under which the tax is imposed, or to failure to file return with respect to a tax or pay a tax.

(4) ... The term 'recovery exclusion', with respect to a bad debt, prior tax, or delinquency amount, means the amount, determined in accordance with regulations prescribed by the Secretary or his delegate, of the deductions or credits allowed, on account of such bad debt, prior tax, or delinquency amount, which did not result in a reduction of the taxpayer's tax under this subtitle (not including the accumulated earnings tax imposed by section 531 or the tax on personal holding companies imposed by section 541 ) or corresponding provisions of prior income tax laws (other than subchapter $E$ of chapter 2 of the Internal Revenue Code of 1939, relating to World War II excess profits tax), reduced by the amount excludable in previous taxable years with respect to such debt, tax, or amount under this section." INT. REv. CoDE of 1954, \$§ 111(a)-(b).

For general discussions of the tax benefit rule, see Atlas, Tax Free Recoveries: The Taz Benefit Rule, N.Y.U. 9re Inst. on Fed. TAx. 847 (1951) ; Plumb, The Tax Benefit Rule Today, 57 Harv. L. Rev. 129 (1943); Plumb, The Tax Benefit Rule Tomorrowe, 57 Harv. L. Kev. 675 (1944); Tye, The Tax Benefit Doctrine Reexamined, 3 TAx L. Rev. 329 (1948); Note, 29 CoRnell L.Q. 515 (1944); Note, Application of the Tax Benefit Rule, 27 N.Y.U.L. REv. 133 (1952); see also 1 MERTENS $\$ 8.34-37$ (collecting cases).

Before being codified in the Revenue Act of 1942, § 116(a), 56 STAT. 812, the tax benefit rule did not enjoy consistent application. The Board of Tax Appeals originally held that recoveries in respect of nonbeneficial deductions were taxable, but later reversed that position. Meanwhile, the Bureau of Internal Revenue gradually expanded the tax benefit rule to exclude from income recoveries in respect of bad debts and tax refunds, but then revoked rulings on the subject and in effect repealed the rule. The Board of Tax Appeals declined to recognize the Bureau's abandonment of the rule but was reversed by the federal courts. To clarify the situation, Congress enacted what is now $\S 111$ of the 1954 Code. Plumb, The Tax Benefit Rule Today, 57 HaRv. L. Rev. 129, 131-33 (1943).

27. See INT. REv. CODE of 1954, § 111, quoted note 26 supra. 
penditures and accruals made the basis for deductions from gross income."28

In the year of recovery, the dollar amount of restored section 111 items which is excludable from income, called the "recovery exclusion," consists of the potential recovery exclusion in the year of the orginal tax deduction or credit, as adjusted. ${ }^{29}$ The potential recovery exclusion is that portion of section 111 items initially deducted without affecting tax liability and is determined by taking away from the total sum of section 111 items in the original year the amount of those items which reduced tax. ${ }^{30}$ The latter amount represents the original year's income computed with section 111 items less its taxable income computed without section 111 items (with the subtrahend never less than zero)..$^{31}$ Once the potential recovery exclusion for the original year is ascertained, the taxpayer makes the required adjustments to it by subtracting both excludable recoveries received during intervening years on account of section 111 items for the original year and the aggregate of those same items which reduced tax in any year through carryovers. ${ }^{32}$ Calculation of tax reduction in a carryover year proceeds in the manner outlined for the original year. ${ }^{33}$

This prescribed method for computing the recovery exclusion operates to accord taxpayers the most favorable possible treatment under the tax benefit rule. Since a recouped section 111 item is tax immune to the full extent of the recovery exclusion, the largest possible amount deducted without tax benefit during the original year is allocated to the recouped item. In effect, a prior deduction with respect to a particular recouped item is presumed to have been the last deduction taken in the original year, ${ }^{34}$ and the resulting exclusion from the taxable year's gross income is thus maximized.

Furthermore, the Tax Court has allowed the tax benefit rule to govern recoveries of past undeducted losses and expenses, although section 111 and the accompanying Treasury regulations do not expressly sanction the exclusion of these sums from current income. ${ }^{35}$ Presumably considering such recoveries

28. T.D. 5454, 1945-1 CuM. Bull. 68; see Dobson v. Commissioner, 320 U.S. 489, 506 (1943) (stock losses) ; Tuttle v. United States, 122 Ct. Cl. 1, 101 F. Supp. 532 (1951); Western Adjustment \& Inspection Co., 45 B.T.A. 721, 728-29 (1941) (business expense).

29. U.S. Treas. Reg. \$ 1.111-1(b) (2) (1956).

30. Ibid.

31. Id. $\S 1.111-1$ (b) (2) (ii) (a).

32. Id. $\$ 1.111-1$ (b) (1). "For this determination of the recovery exclusion, the aggregate of the section 111 items must be further decreased by the portion thereof which caused a reduction in tax in preceding or succeeding taxable years through any net operating loss carryovers or carrybacks or capital loss carryovers affected by such items." Id. § $1.111-1$ (b) (2) (ii) (b) (in part).

33. Ibid.

34. See Plumb, The Tax Benefit Rule Today, 57 Harv. L. Rev. 129, 151 (1943).

35. See cases cited notes 36,37 infra.

Section 111 expressly sanctions only the exclusion of recoveries (as adjusted) equivalent to "the amount ... of the deductions or credits allowed ... which did not result in a reduction of the taxpayer's tax . . . " INT. REv. Cone of 1954, § 111(b) (4). "The rule of exclusion so prescribed by statute applies equally with respect to all other losses, expenditures, and accruals made the basis of deductions from gross income for prior taxable years." U.S. Treas. Reg. § 1.111-1(a) (1956). 
to be returns of capital rather than economic gain, the court has permitted the exclusion of bad debt recoupments from income in cases in which the debts were charged off but not deducted. ${ }^{36}$ In another instance in which no deduction was taken, the court held the reimbursement of losses nontaxable when the deduction would have proved of no tax benefit if taken. ${ }^{37}$ The same result could follow even if a deduction would have proved beneficial provided the loss was genuine when incurred.

On the other hand, in $A . J$. Mandt, the Tax Court voiced dictum inconsistent with the most favorable use of the rule. ${ }^{38}$ The taxpayer had sustained a $\$ 650$ capital loss on the sale of a farm during a year in which his net capital losses totaled $\$ 17,500$. Since deductions for a noncorporate net capital loss are limited to $\$ 1,000$ in any year, the $\$ 650$ loss did not change the amount by which tax liability could be reduced. ${ }^{39}$ As part consideration for the farm, the taxpayer had received an $\$ 8,000$ note having a small fair market value. When the note was eventually paid in full, he attempted to exclude from gross income an amount equal to the original $\$ 650$ deduction. But the Tax Court, observing that $\$ 1,000$ of net capital loss had been used to offset taxable income in the year of the $\$ 650$ loss, reasoned that the $\$ 650$ had been of some benefit because all of the capital losses had contributed proportionately to the beneficial $\$ 1,000$ deduction. ${ }^{40}$

Having viewed each loss in a year of beneficial deductions as necessarily conferring partial tax benefit, the Mandt court implied a "taint" theory precluding a recovery exclusion with respect to that portion of the $\$ 650$ which yielded no tax benefit. ${ }^{41}$ Under such a theory, once an item is deemed to have

36. First Nat'l Bank, Forth Worth, P-H 1943 T.C. Mem. Dec. ff 43073, at 219; J. P. Bass Publishing Co., 12 B.T.A. 728 (1928); see also Plumb, The Tax Benefit Rule Today, 57 HaRv. L. Rev. 129, 131 n.11, 133 \& n.20 (1943) ; cf. Bradford v. Commissioner, 233 F.2d 935 (6th Cir. 1956) (taxpayer held not to realize gain on discharge of debt at less than face value since no economic gain was apparent).

37. Birmingham Terminal Co., 17 T.C. 1011 (1951).

38. P-H 1955 T.C. Mem. Dec. $\llbracket 55226$.

39. INT. Rev. CODE oF 1954, § 1211 (b).

40. "No authority exists ... for breaking down the total capital losses sustained in one year into component transactions, or for applying thereto a procedure such as the first in first out rule to determine which loss or losses are represented in the $\$ 1,000$ deduction so determined. To the contrary, some portion of every capital loss so sustained, minute though it may be, is properly allocable thereto." P-H 1955 T.C. Mem. Dec. II 55226 , at 768 .

41. Mandt apparently misconstrued the Treasury regulations governing the attribution of recoveries to prior deductions. See note 42 infra and accompanying text. Nonetheless, the Mandt court probably decided the recovery issue correctly. Only $\$ 1,000$ of the $\$ 17,500$ total capital loss had actually been allowed as a deduction from gross income. See INT. Rev. Code of 1954, § 1211 (b). The remainder-\$16,500-was undeducted capital loss. Allocation of the $\$ 650$ to the $\$ 16,500$ would necessarily mean that the $\$ 650$ had not been deducted. Since $\$ 111$ grants recovery exclusions only to items previously made the basis for nonbeneficial deductions from gross income, the $\$ 650$ was technically ineligible for exclusion. See $i d$. $\S 111$ (b). Furthermore, receipt of an $\$ 8,000$ note with a 
furnished some fraction of a beneficial deduction, the entire item becomes unusable as the source of a subsequent recovery exclusion. A nonbeneficial deduction could thus arise only in a year when no deduction is used to offset income, that is, when the taxpayer has no gross income at all. Mandt could also be read to imply that if one of several deductions by itself exceeds total tax benefit, that part of the single deduction affording no tax benefit will be tainted.

The Mandt implications are unlikely to prove viable, for they are inconsistent with Treasury regulations attributing all possible nonbenefit of a given year to items in respect of which recovery exclusions are claimed.42 Under the Treasury's approach, so long as any full or partial deduction can be viewed as having been taken without tax benefit, it will be so treated. Applying this formula, a court would regard a prior beneficial deduction as derived from a portion of the earlier loss other than that recovered. Since the beneficial deduction would have been available even without the recovered loss, to say, as in Mandt, that that loss necessarily contributed to the deduction is both illogical and inaccurate.

\section{Business Bad Debts}

In the year a business bad debt becomes partially worthless, the creditortaxpayer may at his option deduct the amount of worthlessness; if he does, the debt's basis is reduced to the extent of the deduction. ${ }^{43}$ Failure to take the deduction immediately does not preclude later deductions for partial or

market value of $\$ 1,000$ completed the farm sale transaction. Later recovery of the note's full face value, of which the taxpayer sought to exclude $\$ 650$ as a recovery in respect of a capital loss, amounted to a new transaction outside the scope of tax benefit relief. See Waynesboro Knitting Co. v. Commissioner, 225 F.2d 477 (3rd Cir. 1955); Allen v. Trust Co., 180 F.2d 527 (5th Cir. 1950). Nevertheless, the Mandt court alluded to neither of these legitimate objections to a tax-free return of the $\$ 650$, and implied instead a proportional theory of recovery allocation.

42. "The recovery exclusion for the taxable year . . . is the portion of the aggregate amount of ... deductions or credits which could be disallowed without causing an increase in any tax of the taxpayer . ..." U.S. Treas. Reg. $\$ 1.111-1$ (b) (2) (i) (1956). See, generally, Plumb, The Tax Benefit Rule Today, 57 Harv. L. Rev. 129, 153-55 (1943) (discussing origins of the regulations).

43. INT. REv. CoDE of 1954, $\$ 166$ (bad debts), 1016(a) (1) (adjustments to basis). Losses from the worthlessness of bad debts are deductible only under the bad debt section of the Code, and taxpayers failing to qualify under that section cannot claim deductions under the loss provisions of $\$ 165$. See Spring City Foundry Co. v. Commissioner, 292 U.S. 182, 189 (1934). But see note 48 infra. Except for debts evidenced by a bond, note or other security, worthless corporate and business debts give rise to ordinary deductions. INT. Rev. CODE of 1954, $\S \$ 166(\mathrm{a})$, (b), (e). Nonbusiness debts are treated as shortterm capital losses. Id. $\S 166$ (d) (1) (B). Worthlessness of debts evidenced by a security is treated as a loss from the sale of a capital asset on the last day of the year of worthlessness. Id. $\$ \S 165(\mathrm{~g}), 166(\mathrm{e})$. Bad debt and loss deductions by banks are governed by $\S 582$, which provides an ordinary deduction for a net loss arising from sales of debts in the form of securities. 
total worthlessness. ${ }^{44}$ If a debt becomes completely valueless, however, a deduction is allowed only for the year in which the worthlessness occurred. ${ }^{45}$ Consequently, a taxpayer without taxable income in the first fiscal year of total worthlessness is confined to a deduction which requires him to write down the debt's basis to zero, affords him no tax benefit and grants him only the possibility of a carryover offset. Therefore, payment or sale of the debt subsequent to a deduction for worthlessness will normally produce taxable income, since the entire proceeds will exceed the adjusted basis. ${ }^{46}$ If the deduction was nonbeneficial and the loss carryover was never utilized, taxation of the proceeds constitutes a levy on return of capital. ${ }^{47}$ To avoid this result, section 111 excludes a bad debt recovery from income to the extent that the deduction for worthlessness was of no tax benefit. ${ }^{48}$

44. See, e.g., Blair v. Commissioner, 91 F.2d 992, 994 (2d Cir. 1937). Deductions for partial worthlessness may be taken only in respect of specific business and corporate debts. INT. Rev. Cone of 1954, § 166(d) (1) (A) ; Proposed U.S. Treas. Reg. § 1.166-1 (c) (3) (1956).

45. "There shall be allowed as a deduction any debt which becomes worthless within the taxable year." INT. REV. CODE of 1954, § 166(a)(1).

Thus, no authority is given for taking deductions for debts which became worthless before the taxable year. See, e.g., Watkins v. Glenn, 88 F. Supp. 70 (W.D. Ky. 1950).

46. See Proposed U.S. Treas. Reg. § 1.166-1(c) (3) (1956).

47. "It is well settled that in the ordinary case amounts received in repayment of loans do not constitute income but are reimbursements of capital. . . Unless a taxpayer has already recovered his capital for income tax purposes, recoveries with respect to a debt . . . cannot be considered as income." G.C.M. 20854, 1939-1 Cun. Bull. 102-03. See also Note, 29 CORNell L.Q. 515, 516 \& n.6 (1944).

48. INT. Rev. CoDe of 1954, §§ 111(a)-(b).

When no deduction for worthlessness is taken, however, the consequences are unclear. If the debt has once been wholly valueless, eventual part payment does not furnish an occasion for deducting the unpaid portion of the debt. See note 45 supra. Ambiguous Code provisions may nevertheless allow basis to remain unaffected. The basis adjustment section provides merely that: "Proper adjustment ... shall in all cases be made for . . . items, properly chargeable to capital account . . ." INT. REv. CoDE of 1954, § 1016(a) (1). Since sale of property at a price less than basis gives rise to a deduction for loss, rather than worthlessness, $i d$. $\S \S 1001-02$, sale of a previously worthless but undeducted debt might produce a loss deduction even though no bad debt deduction for worthlessness would be allowable, cf. Levy v. Commissioner, 131 F.2d 544 (2d Cir. 1942), cert. denied, 318 U.S. 780 (1943) (having sold debt at loss, taxpayer permitted deduction for loss on sale of capital asset, but not a deduction for worthlessness); Von Hoffman Corp., 1957 P-H T.C. Mem. Dec. If 57127 (same); John F. B. Mitchell, 13 T.C. 368 (1949), rev'd on other grotuds, Mitchell v. Commissioner, 187 F.2d 706 (2d Cir. 1951) (if taxpayer partially charges off a note and later in same fiscal year sells the note at price equaling reduced basis, he may not deduct the charge-off but may take a capital loss deduction). If the debt is found to have been totally worthless, however, the deduction will probably be disallowed as tantamount to a deduction for worthlessness. Such has been the result when previously worthless stock was sold for nominal consideration. See, e.g., De Loss v. Commissioner, 28 F.2d 803 (2d Cir. 1928) ; Wilbert Garrison, 1947 P-H T.C. Mem. Dec. ff 47002. Possibly, however, subsequent bona fide sale or payment of the debt will be deemed evidence that the debt had been only partially-though perhaps almost entirely-worthless. See Blair v. Commissioner, 91 F.2d 992 (2d Cir. 1937). There, $\$ 447,000$ in notes were sold 


\section{Bad Debt Reserves}

Rather than take a separate deduction each time a specific debt becomes worthless, the business taxpayer ordinarily deducts from gross income his annual additions to a reserve for bad debts. ${ }^{49}$ Each addition is an expense of doing business, since the balance in the reserve represents estimated debt worthlessness for a given period. ${ }^{50}$ When a specific debt becomes uncollectible, it is charged against the reserve, thus reducing the balance. ${ }^{51}$ If the debt is later paid or sold, the reserve is usually increased by the amount of the recovery, ${ }^{52}$ although recoveries are sometimes treated as ordinary income. ${ }^{53}$ Should the reserve prove excessive or unnecessary, it can be reduced or eliminated by a transfer to income ${ }^{54}$ the transfer may not be taxable if all additions comprising the reserve produced no tax benefit when added.55

for $\$ 710$ to secure a deductible loss to offset gains. The deduction was allowed on the ground that the debt had only been partially worthless, the court stating that: "If the taxpayer has reasonable expectation that the debt or any part of it may be paid, he is under no duty to charge it off. ... [O [O]rdinarily in making this determination he is allowed a fair degree of latitude." Id. at 994. But see Watkins v. Glenn, 88 F. Supp. 70 (W.D. Ky. 1950) (possibility of realizing $\$ 119$ no ground for refusing to charge off $\$ 77,000$ debt as totally worthless). Since deductions for partial worthlessness need not be taken immediately but may be postponed until a later year or until total worthlessness, a loss on sale or payment would be deductible. If nonbeneficial deductions are not taken, a high basis is thus maintained and no later beneficial deduction becomes available, although proceeds from a subsequent sale or payment may nevertheless avoid tax as a return of capital. For recovery produces income only to the extent that the proceeds exceed adjusted basis. See INT. Rev. Cone of 1954, \$ 1001 (a). In light of the tax benefit rule, however, omitting present nonbeneficial deductions in order to exclude later recoveries from income is not only unnecessary but risky as well. Courts may hold that worthlessness requires basis reduction whether a deduction is taken or not. Cf. Plumb, The Tax Benefit Rule Today, 57 HARv. L. Rev. 129, $132 \mathrm{n} .12$ (1943) (basis of depreciable property must be reduced by amount of allowable deduction even though, at that time, no such statutory requirement). Were a court so to hold, a subsequent recovery would exceed adjusted basis and be taxed. Moreover, despite authority to the contrary, see cases cited note 50 infra, the tax benefit rule might be held not to apply in the absence of a deduction, see U.S. Treas. Reg. $\S$ 1.111-1(a) (1956). But see Plumb, supra at 131 n.11, 133 n.20.

49. See FinNey \& Oldberg, Lawyer's Guide to Accounting 53-54 (1955). If "reasonable," additions to reserves for bad debts are deductible. Inr. Rev. CoDE of 1954, § 166 (c). See Vernon, Bad Debt Reserves for Banks, 4 TAX L. REv. 53-54 (1948).

50. Finney \& Miller, Principles of Accounting-Introductory 93-95, 260 (5th ed. 1957) (hereinafter cited as Finney \& Miller). See, e.g., Zellerbach Paper Co., 8 T.C. 511, 512-13 (1947); cf. Ohio Loan \& Discount Co., 3 T.C. 849, 850 (1944).

51. Finney \& Miller 94, 265; Vernon, supra note 49, at 53-54.

52. M \& E Corp., 7 T.C. 1276, 1279 (1946); FinNey \& Millier 262-63.

53. Ibid. Recoveries were treated as ordinary income in J. F. Johnson Lumber Co., 3 T.C. 1160, 1162 (1944); Ohio Loan \& Discount Co., 3 T.C. 849, 850 (1944).

54. See M \& E Corp., 7 T.C. 1276, 1279-80 (1946); see also Zellerbach Paper Co., 8 T.C. $511,514-16$ (1947).

55. M \& E Corp., supra note 54, at 1279-80. If the reserve consists of additions from which the taxpayer derived tax benefit, transfer of a final reserve to income would doubtless be taxable. 
The regulations do not authorize application of the tax benefit rule when a reserve-method taxpayer recovers a bad debt previously charged off against the reserve as worthless. Since the charge-off did not constitute a deduction, the recovery cannot be an amount received in respect of a prior nonbeneficial deduction as required by the regulations' definition of recovery exclusion. ${ }^{56}$ Superficially, denial of tax benefit relief would appear justified, for recoveries are customarily not included as such in gross income but are credited to the bad debt reserve. ${ }^{57}$ Tax avoidance, however, is illusory. Sooner or later, the amount of the recovery will be taxed. If, in the year of recovery, the taxpayer planned an addition to his reserve to provide for the uncollectibility of new debts or an increased rate of default on old ones, he would have had a deduction from ordinary income in the amount of the addition. ${ }^{58}$ But his credits to the reserve for bad debt recoveries will decrease pro tanto the amount which must be added from ordinary income to yield the desired balance in the reserve account. ${ }^{59}$ While inclusion of the recovery amount in the reserve is not a taxable occasion, an equal amount of ordinary income-which would have been added to the reserve and deducted from gross income but for the recoverywill now be taxed. ${ }^{60}$ On the other hand, if the taxpayer would not have increased his reserve in the year of recovery, the recovery produces an unduly large reserve. The Commissioner can then require that the reserve be reduced to proper size, either in the current or a subsequent year; when the reduction occurs, an amount equal to the recovery is transferred to income and taxed. ${ }^{61}$ If the reserve is allowed to remain large in expectation of future needs, additions to it will be smaller in later years, so that the earlier recovery will serve to reduce the taxpayer's deductions-and thus increase his taxable incomein succeeding years. ${ }^{62}$ In summary, recovery of a bad debt by a taxpayer employing a reserve will result in the amount of the recovery being included in the computation of taxable income for one year or another. A refusal to apply tax benefit doctrine to the debt recovery of reserve-method taxpayers is therefore not required in order to prevent tax avoidance.

Nor is denial of tax benefit relief to reserve-method taxpayers supportable on the ground advanced by the Treasury-that, when such taxpayers write off an uncollectible debt, they do not take a deduction. ${ }^{63}$ Charging off a debt reduces the bad debt reserve by an amount which, when initially placed in the

56. U.S. Treas. Reg. $\$ 1.111-1$ (a) (1) (1956) ; Vernon, supra note 49, at 56.

57. See Finney \& Miller 262-63; cf. J. F. Johnson Lumber Co., 3 T.C. 1160, 1162 (1944).

58. See notes 49,50 supra and accompanying text.

59. See Zellerbach Paper Co., 8 T.C. 511, 514-15 (1947).

60. See Boyd-Richardson Co., 5 T.C. 695, 697 (1945).

61. See, e.g., C. P. Ford \& Co., 28 B.T.A. 156 (1933); see also Proposed U.S. Treas. Reg. $\$ 1.166-6$ (b) (1956); 2 CCH 1958 Stand. Fed. TAX Rep. I 1624.117 (collecting cases).

62. See text at notes $58-60$ supra.

63. See U.S. Treas. Reg. $§ 1.111-1$ (a) (1) (1956). 
reserve to provide for that debt, gave rise to a deduction. ${ }^{64}$ Thus, the essential distinction between taxpayers with a reserve and those without is that the latter postpone deductions until the specific worthless debt is ascertained, while the former take deductions when future worthlessness is calculable but the particular debt which will become uncollectible is still unknown. ${ }^{\text {65 }}$ Accordingly, the reserve-method taxpayer recouping a previously charged-off debt and receiving no tax benefit from additions to the reserve occupies the same economic position as the taxpayer who receives no tax benefit on deducting a bad debt. Since the Code expressly permits tax-free recovery of the debt itself,, 0 the same treatment should be accorded analogous credits to bad debt reserves. Specifically, the taxability of a recovery credited to a reserve should depend on the tax benefit derived in earlier years from the additions constituting the reserve.

If the reserve was formed entirely of additions furnishing fully beneficial deductions, a recovery should be included in gross income. Conversely, an exclusion in the amount of the recovery should be granted if the entire reserve represents nonbeneficial deductions. Thus, a recovery could be excluded from gross income whether occasioning tax liability because treated as a cash receipt or obviating an equivalent, tax-deductible addition because credited directly to the reserve. In both instances, excluding the recovery would produce the same tax savings. ${ }^{67}$ Moreover, no tax advantage would result from crediting the recovery directly to the reserve and thereby avoiding an income tax on the recovery itself, since a taxpayer who treats recoupment as a cash receipt obtains a full deduction whenever he adds to the reserve. ${ }^{68}$

A reserve may comprise additions which afforded both beneficial and nonbeneficial deductions. To determine the properly excludable fraction of a bad debt recovery in this situation, an allocation must be made. Conceivably, the exclusion might bear the same relation to the recovery as that part of the reserve

64. See notes 49,50 supra and accompanying text.

65. "The creation of valuation reserves to reduce assets to estimated realizable values is also directly associated with the determination of net income. A failure to recognize the prospect of uncollectible customers' accounts would not only result in an overstatement of current assets, but also in an equal overstatement of net income. . . . In the case of the provision for uncollectible accounts, the inability to forecast the identity of the specific accounts that will prove to be uncollectible makes it impossible to carry the credit direct to the asset account, Accounts Receivable .... The use of a reserve account is intended to tell the statement user that a loss is sufficiently probable to justify its recognition in the accounts, but that the amount of the loss can at present be estimated only." Finney \& Mitler, Princtiples of Accounting-Intermediate 578-79 (4th ed. 1951).

66. INT. Rev. CoDE of 1954, §§ 111 (a)-(b).

67. See text at notes 58-62 supra. Of course, fluctuating income and tax rates over the years could vary the tax savings resulting from a recovery which is credited to the reserve in one year, later eliminating the necessity for a tax deductible addition in another year. Cf. Surrey \& Warren, The Income Tax Project of the American Lawi Institute: Gross Income, Deductions, Accounting, Gains and Losses, Cancellation of Indebtedness, 66 Harv. L. REv. 761, 797-98 (1953).

68. The deduction is authorized by INT. REv. CoDE of 1954, \& 166(c). 
attributable to nonbeneficial additions from income does to the whole reserve. The tax benefit rule, however, permits full attribution of a particular recovered item to nonbeneficial deductions wherever possible, and the Treasury has rejected pro rata allocation. ${ }^{69}$ Alternatively, additions to the reserve in respect of the recovered debt could be deemed made in the year the debt arose, so that recovery would then be excluded from income to the extent that additions to the reserve in that year did not yield tax benefit. ${ }^{70}$ But this assumption wrongly characterizes each addition to the reserve as earmarked for a particular bad debt. ${ }^{71}$ Furthermore, it prevents full achievement of the policy underlying the tax benefit rule-tax-free recovery of capital..$^{22}$ Consequently, recovery should be excluded to the extent that additions to the reserve, regardless of year, produced nonbeneficial deductions. This proposed rule is analogous to the formula which governs allocation of a recoupment among deductions in a given prior year. Here, as there, any nonbeneficial deductions would be considered as taken with respect to the recovered debt. ${ }^{73}$

Thus, revenue policy would not inhibit the utilization of an important accounting device which frequently reveals a more accurate picture of the taxpayer's financial position than does the postponement of deductions until specific worthless debts are identified. ${ }^{74}$ Moreover, section 111 would then conform with the Code provision sanctioning use of a reserve to provide for bad debts, ${ }^{75}$ and with case law permitting reserve-method taxpayers to regard charged-off bad debts as deductions. ${ }^{76}$ For the foregoing reasons, section 111 should be interpreted to include recoveries in respect of bad debts previously charged against a reserve, and the Treasury regulations should be rejected in so far as they deny tax benefit principles to reserve-method taxpayers. ${ }^{77}$

69. See S. REP. No. 1631, 77th Cong., 2d Sess. 80 (1942) ; Plumb, The Tax Benefit Rule Today, 57 HaRv. L. REv. 129, 152-55 (1943).

70. Cf. Finney \& MirLer 260.

71. See note 65 supra and accompanying text.

72. See 55 Harv. L. REv. 1217, 1218 (1942).

73. See note 42 supra and accompanying text. The proposed method of allocation focuses on the total amount of nonbeneficial deductions taken for a given type of item regardless of year, and is similar to the allocation procedure for war loss recoveries. If some war losses were deducted without tax benefit and others with, recoveries in respect of any war losses are excludable up to the aggregate amount of the nonbeneficial deductions. See INT. Rev. Code of 1954, §§ 1332(b) (1)-(2) ; U.S. Treas. Reg. § 1.1332-1(b) (1956).

74. See Finney \& MILIER 93.

75. INT. REv. CoDE of 1954, § 166 (c).

76. See Zellerbach Paper Co., 8 T.C. 511 (1947) ; Boyd-Richardson Co., 5 T.C. 695 (1945); J. F. Johnson Lumber Co., 3 T.C. 1160 (1944).

77. Specifically, the second sentence of U.S. Treas. Reg. \$ 1.111-1(a) (1) (1956) should be amended to allow the exclusion of recoveries in respect of prior nonbeneficial reserve additions.

In 1946, a similar amendment of the regulations accorded reserve-method taxpayers the right to exclude from excess profits tax certain bad debt recoveries if additions to the bad debt reserve had not proved beneficial for tax purposes. T.D. 5496, 1946-1 CuM. 


\section{Writedozens of Inventoried Debts}

Dealers in securities who inventory debts at the lower of cost or market 78 were held ineligible for tax benefit relief in Union Trust Co. $v$. United States. ${ }^{70}$ There, a dealer annually adjusted his closing inventory by writing down bonds to the lower of cost or market. Closing inventory was subtracted from opening inventory in the computation of the cost of goods sold, which was then deducted from gross receipts to yield gross income. ${ }^{80}$ By increasing the cost of goods sold, the writedown of closing inventory reduced gross income. ${ }^{81}$ When certain bonds whose basis had been reduced in years of net loss were subsequently sold for more than their adjusted basis, ${ }^{82}$ the taxpayer claimed that the proceeds of sale were excludable debt recoveries. The Seventh Circuit denied a recovery exclusion on the ground that inventory writedowns are not bad debt deductions and therefore do not come within the statutory tax benefit provision which furnishes relief based on such deductions. ${ }^{83}$ The court felt that inventory writedowns could not be subsumed under the bad debt category because they do not necessarily represent the irrevocable decline in value needed to justify deductions for partial or total worthlessness. ${ }^{84}$ The decision further rested on the infeasibility of attributing recoveries to specific fungible items written down without tax benefit. ${ }^{85}$

An election to inventory debt securities at the lower of cost or market should not bar tax benefit relief. The argument that an inventoried item loses its identity does not apply when, as in Union Trust, a separate record is kept for each security. ${ }^{86}$ Moreover, denial of tax benefit relief in this situation unjustifiably penalizes the inventory-method taxpayer who has securities for which worthlessness deductions would otherwise have been allowable. Despite the fact that his accounting system enjoys Treasury approval and accurately reflects income, his inventory writedowns, as incorporated in cost of goods sold, are judicially excluded from the coverage of the regulation extending tax benefit treatment to "all . . . losses . . . made the basis for deductions from

Bull. 176; see also T.D. 5421, 1944-1 Cum. Bull. 397. Prior to the amendment of the regulations, this result had received judicial approval despite an absence of statutory language authorizing the exclusion. See Ralphs-Pugh Co., 7 T.C. 325, 332 (1946).

78. Debts may be inventoried by dealers in securities at cost, at market, or at the lower of cost or market. Proposed U.S. Treas. Reg. \$ 1.471-5 (1957).

79. 173 F.2d 54 (7th Cir.), cert. denied, 337 U.S. 940 (1949), reversing 48-1 U.S.T.C. II 9210 (S.D. Ind. 1948), 49 Coluar. I. Rev. 1147 (1949).

80. $48-1$ U.S.T.C. If 9210 , at 12423 .

81. Ibid.

82. Id. at $12423-24$.

83. $173 \mathrm{~F} .2 \mathrm{~d}$ at $55-56$.

84. Of the bonds sold, $40 \%$ were obligations of the United States on which no deduction for partial or total worthlessness would be possible. Id. at 56 . Writedowns for market fluctuations in such bonds, however, are deductible through inventorying them at the lower of cost or market.

85. Id. at 55-56.

86. Ibid. 
gross income."s7 Accounting terminology appears to support this result, for cost of goods sold is not a deduction from gross income but a sum subtracted from gross receipts in computing gross income. ${ }^{88}$ Nevertheless, the cost of goods sold is in effect a deduction taken in arriving at taxable income, and its use in the computation of gross income merely indicates official recognition of conventional accounting practice. ${ }^{89}$ Since tax-free recoupment of cost of goods sold manifests a basic-possibly constitutional-principle of income taxation, ${ }^{90}$ the regulations should be amended to exclude from income recoveries of nonbeneficial inventory writedowns.

\section{The Single-Transaction Requirement}

Fundamental to the tax benefit rule is the requirement that both the recovery and the deduction result from a single, integrated transaction. ${ }^{91}$ Therefore, under the rule only the specific money or property received constitutes a recovery on sale or payment of a bad debt. Subsequent increments in the value of the property, or the proceeds from its sale, are regarded as stemming from a new transaction. Even if the taxpayer receives in full satisfaction of the debt stock with a fair market value smaller than the amount owed, for tax benefit purposes the underlying debt is extinguished. Hence, gain on eventual sale of the stock, although no greater than the unpaid portion of the debt, cannot be excluded from gross income. ${ }^{92}$ Resulting from a new

87. U.S. Treas. Reg. § 1.111-1(a) (1956). "The rule of exclusion so prescribed by statute applies equally with respect to all other losses, expenditures, and accruals made the basis of deductions from gross income for prior taxable years." Ibid.

Treasury approval of inventory valuation at the lower of cost or market is found in Proposed U.S. Treas. Reg. $\$ 1.471-5$ (1957). Although this method of valuation may be unduly conservative, FINNEY \& MrLLER 282-83, Treasury approval must be deemed an acknowledgment that income is accurately reflected, cf. INT. REv. CoDE of 1954, $\S \S 446,471$.

88. See Fin Nex \& MILLER 373.

S9. Cf. T.D. 6028, 1953-2 Cuns. Bull. 100; Rev. Rul. 141, id. at 101.

90. See Magill, Taxable In come 355-59 (rev, ed. 1945) (collecting cases suggesting that cost of goods sold must be deducted from gross receipts before income exists within the meaning of the sixteenth amendment); see also Lela Sullenger, 11 T.C. 1076, 1077 (1948).

91. "[O]ne certain requirement for invoking the tax benefit rule is that there be such an interrelationship between the event which constitutes the loss and the event which constitutes the recovery that they can be considered as parts of one and the same transaction." Sloane v. Commissioner, 188 F.2d 254, 262 (6th Cir. 1951).

A similar requirement stipulates that it must be the same taxpayer taking the deduction and claiming the recovery. See Rice Drug Co. v. Commissioner, 175 F.2d 681 (3d Cir. 1949). For application of the so-called single-taxpayer standard to affiliated corporations, trusts and estates, partnerships and joint returns, see Tye, The Tax Benefit Doctrine Reexamined, 3 TAX L. Rev. 329, 333-37 (1948).

92. "[T] $[\mathrm{Tis}$ income did not arise from a payment by the debtor or from a sale of the debt. The pledged shares of stock had no more relation to the debt than the shares of some totally unrelated corporation would have had. The acquisition of the stock in satisfaction of the debt ... was a total termination of the debt and the beginning of a new and separate transaction." Allen v. Trust Co., 180 F.2d 527, 528 (5th Cir. 1950). 
transaction, the gain is not deemed a recovery of a bad debt. ${ }^{93} \mathrm{~A}$ different result could obtain if the debtor assigned the stock as collateral. Inasmuch as price increases or accumulated dividends may then be credited against the amount due from the debtor, they represent a form of payment which might be excludable from income as bad debt recoveries. ${ }^{94}$

Because the receipt of stock in satisfaction of a debt leaves the taxpayer with unrecovered capital when the stock's value is less than the cost basis of the debt, the exclusion of a subsequently realized increment in the stock's worth might appear justified to the extent that the increment represents the unrecovered debt. But this reasoning implies that if the creditor sells the stock in order to invest in different shares, later gain on the new stock could also be deemed a capital recovery. On the other hand, allowing realized increments on the original but not on the new stock to go untaxed would presumably impede the transfer of investment capital to more profitable ventures since, to make a transfer worthwhile, the new stock must then yield more after taxes on the increments than the old stock yielded in the absence of such taxes. This objectionable distinction could be avoided by permitting taxpayers to segregate the new stock and to exclude from income any subsequent gains from that stock until the original debt amount had been recovered. Segregation of this sort, however, necessitates complex and economically wasteful paperwork in order to trace the original property received from the debtor through its transformations in the hands of the creditor. An alternative and simpler solution would permit gain from any source to be excluded from income as an economic restoration of the loss on the debt. So excluding one venture's gains until another venture's losses have been recouped would convert the operation of tax benefit rule into a procedure resembling loss carryovers unlimited in time. Thus, the obstacles to capital recoupment presented by the single-transaction requirement might better be eliminated through actual loss carryovers than through the quasi carryover effect created by a liberalized definition of tax benefit recoveries. ${ }^{95}$

\section{Partial Worthlessness}

The regulations presume that, if a taxpayer took deductions for partial worthlessness of the same item in different years, a subsequent recovery relates to

93. Allen v. Trust Co., supra note 92; see also Waynesboro Knitting Co. v. Commissioner, 225 F.2d 477 (3d Cir. 1955).

94. Since assignment of stock as collateral would not extinguish the underlying debt, subsequent payments out of stock proceeds of increased value would not constitute a separate transaction. Thus, the proscription found in Allen v. Trust Co., 180 F.2d 527 (5th Cir. 1950), would be inapposite. There, the court said: "We think the tax benefit rule ... is not applicable to this case, because the making of the loan in 1931, the acceptance of the stock in 1932 in cancellation of the debt, and the subsequent sale of the stock at a gain in 1940, were not parts of one integrated transaction." Id. at 528.

95. See text at note 160 infra. 
those deductions which did not reduce tax liability. ${ }^{96}$ Thus, the taxpayer need not prove that recovery arose only from the nonbeneficial deductions. If nonbeneficial deductions for partial worthlessness were taken in two or more years, recovery in excess of remaining basis is first attributed to the most recent deductions, then to the earlier ones in sequence. ${ }^{97}$ The regulations allow an exception to this rule whenever attribution of a debt recoupment to the latest prior year in which a deduction for the debt's partial worthlessness was taken would bar the application of that year's recovery exclusions to a separate amount recovered in respect of another item deducted in the same prior year. Under the exception, recovery exclusions available for that year are first applied against the other item, after which any recovery exclusion remaining is attributed to the debt that gave rise to nonbeneficial partial worthlessness deductions in several prior years. If no recovery exclusion remains for the latest prior year, the debt recovery may then be excluded from income on the basis of the most recent nonbeneficial deduction in an earlier year. ${ }^{98}$

Interplay of the Code's carryover provisions with the tax benefit rule's prescribed attribution order can render the fullest recovery of capital more difficult. The loss carryover and tax benefit sections afford alternative routes to tax relief whenever recovery occurs in respect to an item which was previously deducted without tax benefit and which also composes a net operating loss eligible for carryover in the five-year statutory period. ${ }^{99}$ If two losses of this sort were previously deducted in two different years, and passage of the five-year period bars carryover of the earlier loss but not the later, full use of both is best achieved by activating the tax benefit rule and attributing current recoveries to the deduction of the earlier loss. The first deduction can be utilized only on receiving a related recovery, while the loss underlying the later deduction may still be carried over into a year of taxable income. When further recovery on the debt is unlikely, the earlier deduction may never again prove usable. Consequently, the attribution of recoveries to the earlier year is desirable even if carryover deductions are still available for both years.

96. U.S. Treas. Reg. $\$ 1.111-1$ (a) (3) (1956). If all of the debt has not been charged off, income received on subsequent payment or sale is applied first against the remaining basis. Id. $\S 1.111-1$ (a) (2).

97. Id. $\$ 1.111-1$ (a) (3).

98. Ibid. This allocation procedure can be illustrated by the following example. In 1945 , a year with no taxable income, taxpayer takes a nonbeneficial $\$ 50$ deduction for the partial worthlessness of a $\$ 100$ debt. In 1946 , a year with $\$ 50$ adjusted gross income, taxpayer deducts the remaining $\$ 50$ of the now wholly worthless debt and also deducts another $\$ 50$ for a business loss. In 1949, taxpayer recoups $\$ 50$ in respect of the bad debt and $\$ 50$ in respect of the loss. If the ordinary rule of attribution were followed, the $\$ 50$ debt recovery would be attributed first to the most recent deduction. In this instance, such attribution would exhaust the recovery exclusion for 1946 and prevent tax-free recoupment of the business loss recovery. Consequently, to secure maximum tax benefit, first the recouped business loss is attributed to the 1946 recovery exclusion. Then, since no excess exclusion remains to absorb the bad debt recovery, it is allocated to the earlier year.

99. For discussion of the loss carryover provisions, see notes 9-22 supra and accompanying text. 
Maximization of tax-free capital recoupment thus requires that every recovery be first attributed to the earliest year for which the right to net operating loss will disappear.

\section{Attribution Problems and the Regulations}

Although the regulations cover with specificity the method of attributing bad debt recoveries among beneficial and nonbeneficial deductions, they do not mention other enumerated tax benefit items, such as recovered business expenses and losses, in this context. ${ }^{100}$ Authority exists, however, denying full tax benefit relief on recoupment of a business expense attributable to two deductions, one of which failed to reduce tax liability. In First National Bank, Montoursville, the taxpayer received $\$ 1,050$ as reimbursement for a prior $\$ 1,500$ contribution to a failing bank. ${ }^{101}$ Of the latter amount, $\$ 900$ had been deducted earlier without tax benefit, while the remainder had been separately and beneficially deducted. ${ }^{102}$ Observing that the recovery was seventy per cent of the original contribution, the court allowed a recovery exclusion of $\$ 630$, or seventy per cent of the $\$ 900$ nonbeneficial deduction. ${ }^{103}$

100. See U.S. Treas. Reg. $\S 1.111-1$ (1956). This regulation specifies that the rule of exclusion applies to all losses, expenditures and accruals made the basis of nonbeneficial deductions from gross income. But the regulation discusses the method of computation and allocation solely in terms of recovered bad debts, prior taxes and delinquency amounts.

101. P-H 1943 T.C. Mem. Dec. If 43079. In 1932, the Peoples Bank and Trust Co. of Montoursville merged with the First National Bank of Montoursville to form a new consolidated bank-the instant taxpayer-which took over the assets and assumed the liabilities of the consolidating banks. Prior to the consolidation, the Peoples Bank had contributed $\$ 600$ and the National Bank $\$ 900$ to a neighboring bank experiencing financial difficulties. Having been written off the books of the National Bank as a business expense just prior to the consolidation, the $\$ 900$ appeared as a deduction in the income tax return filed by the consolidated bank for 1932 . In 1939 , the consolidated bank received $\$ 1,050$ as a $70 \%$ repayment of the two contributions.

102. Actually, the taxpayer was simply unable to prove that the $\$ 600$ had been deducted without tax benefit. The court therefore treated the $\$ 600$ as though it had been beneficially deducted. On the other hand, since the $\$ 900$ deduction was proved nonbeneficial, it was deemed subject to partial tax-free recovery. P-H 1943 T.C. Mem. Dec. $斤$ 43079 , at 237.

103. Ibid.

Conceivably, the court could have denied any exclusion at all on either of two grounds.

First, since the consolidation intervened between write-off and recovery, different taxpayers might be said to have sustained the loss and the claimed recovery, thus failing to comply with the tax benefit rule's single taxpayer requirement. See Plumb, The Tax Benefit Rule Today, 57 HaRv. L. REv. 129, 171 \& n.149 (1943). The court did not consider identity questions relevant, possibly because the $\$ 900$, although written off before consolidation, was deducted on the consolidated return and recovered by the consolidated bank.

Second, at the time of the court's decision, the regulation extending tax benefit relief to "all other losses, expenditures, and accruals made the basis of deductions from gross income for prior taxable years," T.D. 5454, 1945-1 Cum. Butu. 68, had not yet been promulgated. Thus, the court could have considered business expenses outside the tax 
A proportional exclusion of this sort seems needlessly restrictive. Instead, the court could have adopted a method of attribution permitting tax-free recovery of that part of the reimbursement previously expended and deducted without tax benefit. So doing, the court would achieve a logical extension of the presumption in the regulations that of all deductions taken in any net loss year, deductions in respect of claimed recoveries were taken last. ${ }^{104}$ In other words, since the regulations in effect provide that those deductions giving rise to eventual recoveries are presumed, wherever possible, to have been nonbeneficial, recoveries could in turn be presumed, wherever possible, to have occurred in respect of nonbeneficial deductions. This presumption, maximizing the rule's potentiality for securing tax-free recoupment of capital, ${ }^{105}$ is already established for cases involving bad debt recoveries charged off in two or more years but with tax benefit in only one. ${ }^{106}$ Whether the taxpayer was repaid on a debt or, as in Montoursville, reimbursed for a business expense should not govern the attribution of recoveries which are returns of capital. Instead, the presumption that recoveries relate to nonbeneficial deductions should apply to all items comprehended by the tax benefit regulations.

A separate problem exists for recoveries not directly related to items covered by the regulations. Reluctant to abrogate annual accounting periods, courts have refused extension of the tax benefit rule to deductions taken in gross, have required that recoveries must be traceable to deductions taken in regard to a specific item, and have placed the evidentiary burden of attributing recovery to a definite res on the taxpayer. ${ }^{107}$ Church's English Shoes, Ltd., furnishes an example. ${ }^{108}$ There, the taxpayer purchased shoes on credit from its parent corporation in England and valued them for inventory and cost of goods sold purposes at a cost based on the then current exchange rate of $\$ 4.86$ per pound sterling. Within its next two fiscal years, the taxpayer sold all the shoes but sustained net operating losses. A debt was carried on the taxpayer's books at the original dollar cost of the shoes until ten years later when Church's paid for them at the going rate of $\$ 4.03$ per pound or approximately $\$ 2,000$ less than the face amount of the debt. Seeking to exclude the $\$ 2,000$ from gross income, the taxpayer argued that this sum represented not gain but diminution of net loss for the two years in which the debt had entered cost of goods sold computations. But the court held the $\$ 2,000$ taxable, reasoning, first, that the currency "speculation" formed a transaction separate from the sale of the shoes and, second, that the taxpayer had failed to identify the particular shoes which had been sold at a loss. ${ }^{109}$

benefit rule because excluded from the statutory items and not yet included by the regulations. See Plumb, supra at 144-45.

104. See U.S. Treas. Reg. $\S 1.111-1$ (b) (1956).

105. Cf. Plumb, The Tax Benefit Rule Today, 57 HARv. L. Rev. 129, 155 (1943).

106. U.S. Treas. Reg. $\S 1.111-1$ (a) (3) (1956).

107. See, e.g., Capitol Coal Corp. v. Commissioner, 250 F.2d 361 (2d Cir. 1957).

108. 24 T.C. 56, aff'd per curiam, 229 F.2d 957 (2d Cir. 1956).

109. 24 T.C. at $57-59$. 
The court wrongly characterized the gain on currency rate fluctuations as a separate transaction. ${ }^{110}$ The source of taxable gain lay in the fact that the taxpayer had fixed the cost of the shoes at $\$ 12,000$ and had subtracted that sum from gross sales in arriving at gross, and hence taxable, income. Since the shoes were eventually paid for in pounds costing $\$ 10,000$, the taxpayer in effect overstated the cost of goods sold and understated income for prior years. Consequently, the $\$ 2,000$ was not gain on speculation but an accounting entry necessary to correct prior understatement of income from sales. The $\$ 2,000$ gain should therefore have been viewed as sufficiently a part of the shoe purchase to constitute a recovery in respect of any loss on sale.

The court also seems unnecessarily severe in requiring that the taxpayer prove a loss on the sale of the exact shoes purchased for the $\$ 12,000$. Unquestionably, no tax benefit resulted from stipulating the cost of goods sold at $\$ 12,000$ rather than $\$ 10,000$, for all the shoes were sold during years of large net loss. ${ }^{111}$ Furthermore, under Code provisions existing since 1939, if goods have not yet been sold at the time that indebtedness is discharged at less than face, the taxpayer can exclude the amount of debt cancellation from gross income by reducing the basis of the goods by an identical amount. ${ }^{112}$ This sum would then escape taxation were the goods eventually sold in a year of net loss-a year in which losses offset the proceeds from the sale calculated on the reduced basis. When the sale occurs prior to the debt cancellation, as in Church, here, too, the taxpayer should be able to use a net loss arising in the year of sale (and not utilized through carryovers) to offset gain realized on discharge of the debt. Unless he thus excludes from present income the amount by which he could have reduced the cost of goods sold in previous years without increasing his taxes in those years, he cannot use the earlier losses to offset present gain. Allowing the current exclusion would simply leave him in the same position as if he had correctly stated the cost of goods sold at the outset.

A retroactive adjustment of purchase price could in effect be achieved-and the Church result avoided-by amending the Treasury regulations and treating

110. Even viewed as a separate transaction, the currency purchase might possibly be considered as not yielding taxable gain on the ground that the taxpayer was merely returning fungible goods previously borrowed. See B.F. Goodrich Co., 1 T.C. 1098 (1943). But if the taxpayer has received a tax benefit from inventorying his goods at the higher "date of purchase" price, this approach would allow him to reduce taxes on account of expenses never incurred. Consequently, courts have not followed the Goodrich case. See, e.g., Willard Helburn, Inc. v. Commissioner, 214 F.2d 815 (1st Cir. 1954). When, however, the transaction as a whole has produced no net gain, no net taxable gain should be found. See William H. Coverdale, P-H 1945 T.C. Mem. Dec. 145240.

111. 24 T.C. at 57. Nonetheless, the taxpayer enjoyed what was in effect a $\$ 2,000$ cancellation of indebtedness which, therefore, constituted income. See Commissioner v. Jacobson, 336 U.S. 28 (1949), 16 U. CHI. L. REV. 725.

112. See Int. Rev. Cone of 1954, $\S 108$ (a), 1017; U.S. Treas. Reg. $\$ 1.1017-1$ (1956); Int. Rev. Code of 1939, $\$ \$ 22$ (b) (9), 113 (b) (3), 53 STar. 875 (applicable only to corporate taxpayers). At the time (1947) that Church's (a corporation) reduced its cost of goods sold by purchasing cheaper pounds, the 1939 Code provision was in effect. 24 T.C. at 58 . Thus, the argument advanced in the text could have been made to the Church court. 
cost of goods sold as a section 111 item. ${ }^{113}$ The tax benefit principles now governing the cancellation of indebtedness would then extend to all items which are subtracted from gross sales in arriving at taxable income. ${ }^{114}$ Hence, the Church taxpayer's $\$ 2,000$ decreased indebtedness would not be included in gross income, because he received no tax benefit from stating in earlier years that his cost of goods sold was $\$ 12,000$ instead of $\$ 10,000$. This proposed extension of the regulations finds support in the fact that, if the $\$ 12,000$ debt had been accrued and deducted as salary expense or interest owed, subsequent discharge for $\$ 10,000$ would give rise to income only if tax benefit accompanied the previous deduction of the extra $\$ 2,000$ of expense. ${ }^{115}$ That the $\$ 12,000$ debt represented goods purchased for sale, rather than services or the use of money, should not change the tax treatment of the debt's cancellation subsequent to sale. ${ }^{110}$

\section{Depreciation and Depletion}

Tax-free recoupment of capital expenditures may ordinarily be achieved through deductions for depreciation or depletion and for loss on resale of a capital item. ${ }^{117}$ By means of depreciation, a taxpayer makes systematic charges to expense in order to deduct the cost of the capital asset over its estimated useful life. ${ }^{118}$ Thus, if the item is retained for its entire life, an amount equal to its cost may be transformed into tax-free income. Similarly, deductions for depletion permit the cost of natural resources to be ratably charged off to expense. ${ }^{110}$ Here, the total allowable deductions usually exceed the original cost because depletion may be computed as a percentage of annual revenue from the property rather than of the original cost. ${ }^{120}$ Under both depreciation and depletion systems, when the taxpayer sells an asset, he subtracts its adjusted basis -the cost not yet recovered through previous deductions-from the proceeds

113. See notes $26-28$ supra and accompanying text.

114. See text at notes $88-90$ supra.

115. See U.S. Treas. Reg. § 1.111-1(a) (1956) (extending tax benefit rule to all "expenses" made the basis for deductions from gross income); Chenango Textile Corp., 1 T.C. 147 (1942) (cancellation of accrued interest); Barnhart-Morrow Consol., 47 B.T.A. 590, 600-01 (1942) (cancellation of accrued salaries not taxable where no tax benefit resulted from deduction); Amsco-Wire Products Corp., 44 B.T.A. 717 (1941) (same).

116. For purposes of the foregoing paragraph, the year the property was sold means the year in which the property was treated as sold under the taxpayer's method of inventory accounting, since the problem is one of overstating an item in cost of goods sold.

117. See Int. Rev. Code of 1954, §§ 167, 611-14; Grant \& Norton, Depreciation c. 11 (1955).

118. Int. Rev. Code of 1954, § 167; see Grant \& Norton, Depreciation c. 4 (1955).

"Depreciation accounting is a system of accounting which aims to distribute the cost or other basic value of intangible capital assets, less salvage (if any), over the estimated useful life of the unit ... in a systematic and rational manner." FINNEx \& MILLER 290 (quoting the Committee on Terminology of the American Institute of Accountants).

119. INT. REv. CODE of 1954, §§ 611-14.

120. Id. $\$ 613$ (a); see BitTKER, Federal Income Estate AND GIFT TAXation 277-79 (1955). 
of sale in order to exclude unrecovered cost from gross income or to provide a deduction for the amount of any loss. ${ }^{121}$

Mandatory reductions of basis, however, can lessen the efficacy of depreciation and depletion deductions as a means of insuring tax-free return of capital. Each year, the basis of a capital item must be reduced by the amount of depreciation or depletion allowable, irrespective of whether the deduction, if taken, would have produced tax benefit. ${ }^{122}$ Moreover, on selling the asset, the vendor always realizes income in the full amount by which purchase price exceeds the adjusted basis. ${ }^{123}$ If, without tax benefit, he had reduced the basis of an item subject to depreciation or cost depletion, taxing total receipts on sale constitutes a levy on capital. For assets giving rise to percentage depletion, the tax is a levy on capital when the sum of beneficial deductions was less than the amount by which basis had been reduced.

To prevent taxation of capital recoveries, proceeds from the sale of depreciated or depleted property should be excluded from gross income to the extent that basis adjustment was accomplished by nonbeneficial deductions. Statutory amendment is not necessary to effect such tax benefit relief. True, the exclusion of recoveries representing nonbeneficial deductions does, on the sale of depreciable capital items, require deviation from the statutory requirement that total gain be recognized. ${ }^{124}$ Nonetheless, for purposes of further depreciation and loss on sale, deductions would still be determined by reference to basis as reduced under the provisions requiring yearly downward adjustment. ${ }^{125}$ Furthermore, courts have found the Code not to proscribe the exclusion of recoveries for worthless stock after its basis had been reduced by nonbeneficial deductions. ${ }^{126}$ The exclusion of certain recoveries in excess of the adjusted basis of depreciable capital items seems equally justifiable-and equally without express authorization-under the Code. Since the absence of statutory authorization has not prevented the courts and the Treasury from extending

121. INT. Rev. CoDE of 1954, § 1001; Proposed U.S. Treas. Reg. § 1.1001-1 (a) (1957).

122. Int. Rev. CoDE of 1954, § 1016(a) (2) ; Proposed U.S. Treas. Reg. § 1.1016-3 (a) (2) (1957). Generally, if more than the allowable deduction is taken and not disapproved on audit, basis is reduced by the full amount of the deduction allowed. INT. REv. CODE of 1954, $\$ 1016$ (a) (2). However, basis need not be reduced by allowed depreciation deductions which failed to offset taxable income. Id. $\S 1016(\mathrm{a})(2)(B)$; see Proposed U.S. Treas. Reg. $\S 1.1016-3(\mathrm{e})$ (1957). Application of tax benefit principles to excessive, allowed depreciation deductions had been rejected by the Supreme Court prior to the 1954 Code. Virginian Hotel Corp. v. Helvering, 319 U.S. 523 (1943). Virginian Hotel held that, as a matter of law, the cost basis of property must be reduced by depreciation allowed in excess of the amount properly allowable, even though no tax benefit had resulted from the excessive deductions. See Plumb, The Tax Benefit Rule Tomorrow, 57 Harv. L. Rev. 675, 676-77 (1944).

123. INT. Rev. Code of 1954, § 1001 (a); see U.S. Treas. Reg. § 1.111-1(a) (1956).

124. For the requirement that total gain be recognized, see INT. REv. CoDE of 1954, $\$ \$$ 1001-02.

125. See $i d . \S 1016$.

126. Louise Webber O'Brien, 22 T.C. 661,670 (1954) ; Estate of Fred T. MIurphy, 22 T.C. 242, 256 (1954) ; Tuttle v. United States, 122 Ct. Cl. 1, 101 F. Supp. 532 (1951). 
tax benefit relief to losses and expenses not specifically enumerated in section $111,{ }^{127}$ the Treasury should amend the regulations so that tax benefit principles can encompass depletion and depreciation. Even without Treasury action, courts might broaden the scope of tax benefit applicability without usurping legislative functions, for the nature of "income" remains in large measure a matter for judicial determination. ${ }^{128}$

\section{Second Deductions}

Designed simply to exclude recoveries in respect of earlier, nonbeneficial deductions from current income, the tax benefit rule ordinarily does not allow a second deduction even though the first was of no benefit. ${ }^{129}$ If a worthless $\$ 1,000$ debt was deducted without tax benefit, for example, a subsequent recovery of $\$ 700$ in respect of the same debt is excludable from gross income; but the taxpayer cannot then deduct his $\$ 300$ loss on the entire transaction. In effect, the rule permits basis to remain unreduced in computing gain but not in computing loss. ${ }^{130}$ And if the $\$ 300$ is never used to offset income,

127. Louise Webber O'Brien, supra note 126; Birmingham Terminal Co., 17 T.C. 1011, 1014 (1951) (tax benefit rule applied to reimbursement of retirement losses which were never deducted) ; T.D. 5454, 1945-1 CuMr. Bunz. 68 (tax benefit rule extended to all other losses, expenditures and accruals except deductions for depreciation, depletion, amortization or amortizable bond premiums).

128. Case-law evolution of the tax benefit rule before its codification in 1942 is a prime example of judicially formulated income concepts. Granted a virtually free hand by what is now INT. REv. CODE OF 1954, § 61 ("gross income means all income from whatever source derived ..."), courts simply viewed certain income as a return of capital and accordingly excluded it from gross income, see Plumb, The Tax Benefit Rule Today, 57 HaRv. L. Rev. 129, 130-34 (1943). In Dobson v. Commissioner, 320 U.S. 489, 506 (1943), the Court held "that no statute or regulation having the force of one and no principle of law compels the Tax Court to find taxable income in a transaction where as a matter of fact it found no economic gain and no use of the transaction to gain tax benefit." Not included within the tax benefit rule, however, are $\$ 171$ deductions for amortizable bond premiums. U.S. Treas. Reg. $\$ 1.111-1$ (a) (1956). The argument for extending tax benefit to depreciation applies equally to amortization and amortizable bond premiums. See Tye, The Tax Benefit Doctrine Reexamined, 3 TAX L. Rev. 329, 344 (1948).

129. See, e.g., Magruder v. Fidelity \& Deposit Co., 139 F.2d 751, 754 (4th Cir. 1944) : "In 1933, [taxpayer] ... formally charged off this item, claimed and was allowed a deduction therefor, though [taxpayer] ... received no economic benefit, in the way of diminution of its taxes, from the deduction. Then, when 1935 is a prosperous year, so that the allowance again of a deduction would reduce its taxes, [the taxpayer] ... claims that this item must live again, though once it was dead ...." See also Bank of Newberry, 1 T.C. 374, $376-78$ (1942). Double deductions were once recognized by the Treasury. G.C.M. 18525, 1937-1 Cum. Bull. 80. And during the hearings on the 1942 Revenue Act, the suggestion was made that accrued interest deducted without tax benefit should again be allowed as a deduction when actually paid. Hearings Before the Senate Finance Committee on the Revenue Act of 1942, 77th Cong., 2d Sess. 2145-46 (1942). Case law, however, has firmly rejected the second deduction. See Tye, supra note 128 , at 343-44.

130. National Bronx Bank v. Commissioner, 147 F.2d 651 (2d Cir. 1945) (taxpayer's deduction of loss on sale of bonds disallowed although previous deductions for worthlessness were taken without tax benefit); see also First Nat'l Bank, 16 T.C. 147, 153 (1951); Plumb, The Tax Benefit Rule Tomorrow, 57 HARv. L. REv. 675, 679 (1944). 
eventual taxation of an amount of income up to $\$ 300$ represents a levy on unrecovered cost and defeats the rule's underlying policy of securing tax-free recoupment of capital. In one instance, however, tax benefit doctrine does authorize a second deduction. When depreciation or depletion deductions exceed those allowable by statute, but are nonetheless allowed, basis remains undiminished to the extent that the excessive portion of the deductions was of no tax benefit. ${ }^{131}$ Thus, not only will future recoveries of this fraction of the basis be excluded from gross income, but a second deduction may also be taken through sale of the asset at a loss or by depreciation of the undiminished basis. ${ }^{132}$ In all other cases, the tax benefit rule operates not to maintain basis but to exclude recoveries.

While the denial of second deductions may impede tax-free recovery of business expenditures, the administration of tax returns containing second deductions from an unlimited number of previous years might well prove unduly cumbersome. $^{133}$ Second deductions could not be effectively limited to identifiable events like the sale or payment of a debt, because taxpayers could create these occasions at will simply by discharging impecunious debtors for nominal payments or arranging opportune sales. A requirement of genuineness might eliminate second deductions on taxpayer-manufactured events but, absent a presumption of genuineness based on an arbitrary recovery percentage, imprecision of the standard could lead to an undesirable volume of litigation. Although auditing procedure for a second deduction arising from eventual sale or payment of a debt would in each instance be administratively no more burdensome than verifying a claimed recovery exclusion, the overall task of auditing would be greater; loss sales for debts forming the basis of nonbeneficial deductions can be arranged, but excludable recoveries arise fortuitously and less frequently. Still more complex administrative problems would mark a system of second deductions for other items like depreciation, depletion, expenses and losses. Auditing the return of a given year's income under such a system would frequently require reference to many separate events in previous accounting periods.

Finally, second deductions should be contrasted with loss carryovers. The carryover device systematically channels all nonbeneficial deductions for each year into a single net operating loss deduction. ${ }^{134}$ Sham sales become unnecessary and previous nonbeneficial deductions can be used in an orderly manner. Moreover, the Commissioner can verify each annual return by referring simply

131. INT. REv. CODE of 1954, §§ 1016(a)(2)(A)-(B); see note 122 supra.

Under the 1954 Code, allowed depreciation deductions which produced no tax benefit need not be used to reduce basis. Ibid. Such liberalized treatment contrasts with pre-1954 case law. See Virginian Hotel Corp. v. Helvering, 319 U.S. 523 (1943) (basis must be reduced in respect of nonbeneficial depreciation deductions).

132. On loss sales, see INT. Rev. Cone of 1954, §§ 1001 (a)-(b).

133. For some of the administrative difficulties already inherent in tax benefit computations, see Plumb, The Tax Benefit Rule Today, 57 HARv. L. Rev. 129, $151-75$ (1943).

134. See INr. Rev. CoDE of 1954, § 172(c). 
to the net operating losses of earlier years rather than to numerous constituent transactions.

\section{CONCLUSION}

If the tax benefit rule is retained, its expansion is indicated. Taxpayers using reserve-method accounting and security dealers inventorying debts at the lower of cost or market should be able to exclude from income bad debt recoveries in respect of prior nonbeneficial deductions. ${ }^{\mathbf{1 3 5}}$ Moreover, amended regulations should bring amounts entering the cost of goods sold within the ambit of the tax benefit rule by permitting the exclusion of recoveries in respect of any item whose prior subtraction from income did not reduce tax liability. ${ }^{136}$ The rule should also cover depreciation and depletion deductions in order that income not include that amount of sale proceeds representing the recoupment of nonbeneficial deductions. ${ }^{137}$ In addition, recoveries which may be traced to any of several deductions should be first attributed to nonbeneficial deductions. ${ }^{138}$ Were all the foregoing enlargements of the rule achieved, tax benefit relief would become a meaningful supplement to the presently limited loss carryover sections of the Code.

The necessity for extending tax benefit relief is, however, a direct function of the limitations on loss carryovers. At present, the tax benefit and loss carryover provisions are mutually exclusive, interacting devices designed to achieve an identical objective. No rational standard determines whether items are governed by the tax benefit rule-and hence are excludable in connection with a recovery in the indefinite future - or are outside the rule-and hence recoupable only during the carryover period. More important, circumstances may prevent either form of relief. Consider the merchandising business suffering heavy losses during a protracted depression; a tax on its net gain in future prosperous years will represent a levy on receipts needed to counterbalance the accumulated deficits. ${ }^{132}$ Once the loss carryover period has run, the taxpayer cannot utilize past losses since, under tax benefit principles, the requisite transactional identity is lacking between sale proceeds on one group of merchandise units and losses on another. ${ }^{140}$ Although courts readily recognize the inequity of taxing the payment of a debt previously deducted without tax benefit, ${ }^{141}$ they do not treat profits arising from a business previously operated at a loss as tax-free recoveries of business investment-despite the fact that both are equally returns of capital..$^{142}$

135. See text at notes 73,90 supra.

136. See text at notes 113-16 supra.

137. See text at notes 124-28 supra.

138. See text at notes 104-06 supra.

139. See, e.g., Church's English Shoes, Ltd., 24 T.C. 56, aff'd per curiam, 229 F.2d

957 (2d Cir. 1956), discussed notes 108-16 supra and accompanying text.

140. See, c.g., ibid.; see also text at notes $91-95$ supra.

141. See, e.g., National Bank of Commerce, 40 B.T.A. 72 (1939), aff'd on other grounds, 115 F.2d 875 (9th Cir. 1940); see also 55 HARv. L. REv. 1217 (1942).

142. See Beck, Carryover of Business Losses, 6 NaT'L TAX J. 69, 70 (1953). 
Extending the carryover period, rather than broadening tax benefit relief, would be the more efficient way to ensure tax-free capital recoveries. Present policy underlying the tax benefit rule and favoring taxpayers who must relate recoveries back over many years would be better implemented because loss carryovers require reference to only a single annual figure rather than to separate transactions within previous years. ${ }^{143}$ As a replacement for both the current short-term carryovers and the arbitrarily restricted tax benefit rule, a period of fifteen or twenty years seems both feasible and desirable for all carryovers. ${ }^{144}$ Thus enlarged, the carryover period would serve the needs of cyclical businesses particularly sensitive to economic fluctuations. ${ }^{145}$ Moreover, the administrative obstacles to such full utilization of the carryover principle could be minimized by requiring taxpayers who desire extended carryover periods to pay for the added cost of storing records. ${ }^{146}$

Tax-free capital recoupment dictates the extension of loss carryovers in content as well as in time. The Code defines the net operating loss which may be carried over as including business deductions but not other deductions except

143. The requirement that deduction and recoupment must be embodied in the same transaction fails to define with precision what constitutes a single transaction. Whether an apparently integrated transaction is broken up into discrete steps or whether several apparently separate steps are synthesized into a whole transaction are questions often decided without the benefit of a comprehensive rationale. See, e.g., Dobson v. Commissioner, 320 U.S. 489, 502 (1943). Courts sometimes have demanded that the property on which the loss is suffered be traced to the transaction producing the gain. E.g., Capitol Coal Corp., 26 T.C. 1183, 1196 (1956) aff'd per curian, 250 F.2d 361 (2d Cir. 1957) ; Merton E. Farr, 11 T.C. 552, 567 (1948), aff'd sub nom. Sloane v. Commissioner, 188 F.2d 254 (6th Cir. 1951). In contrast to the often vague judicial standard of a single transaction, net loss carryover may be used against any income, thereby making identity considerations immaterial. See INT. REv. CODE OF 1954, § 172(c).

144. For economic considerations which might control the division of the carryover period into subperiods of carryforward and carryback, see Beck, supra note 142.

145. See id. at 70. Industry's recommendations as to length of carryover period are collected in Hearings Before the House Committee on Ways and Means on Forty Topics Pertaining to the General Revision of the Internal Revenue Code, 83d Cong., 1st Sess. 1222-51 (1953). The longest extension requested was by the Machinery and Allied Products Institute (six years carryforward, three years carryback). Id. at $1225-26$.

146. See U.S. Treasury Dep't and JoInt Committee on Internal Revenue TaxATION, Business Loss OfFSETS 2 (1947). Although audit is made more difficult by passage of time, $i d$. at 3 , the taxpayer would retain the burden of proof. Moreover, a longer carryover period would not require significant changes in the present practice of storing old returns. Individual returns are retained for at least six years, and all corporate returns for a longer period. 5 CCH 1958 Stand. Fed. TAX REp. If 5975.011; cf. Greenside, The Importance of the Original Tax Return in Civil Fraud Cases, 36 Taxes 324 i(1958).

Storage costs could be reduced by informing taxpayers with carryovers still unused after a few years that their records are about to be destroyed but that a certified or photostatic copy of the records will be delivered to them for a fee sufficient to cover the cost of auditing and processing. This procedure might allow a longer carryback as well as carryforward period. 
to the extent of ordinary nonbusiness gain and net nonbusiness capital gain. ${ }^{147}$ This curtailment of nonbusiness loss carryovers is inconsistent with the general statutory design that expenditures in profit-seeking ventures be recovered tax free. The Code allows the deduction from current earnings of all expenses incurred for the production of profit, even if the expenses derive from an activity receiving insufficient taxpayer attention to qualify as his trade or business. ${ }^{148}$ Deductions are also available for the depreciation of property held for the production of income, whether or not it is used in a trade or business ${ }^{149}$ and for losses resulting from any transaction entered into for profit. ${ }^{150}$ When these deductions do not yield tax benefit in the year originally taken, they must offset the income of other years in order that tax liability reflect net economic position. ${ }^{151}$ Thus, net operating loss carryovers should include all expenditures made for profit, whether business or nonbusiness.

147. INT. REv. CoDE of 1954, § 172(d) (4). This limitation probably has less overall effect than the restrictions on capital loss carryovers. See $i d . \S 1212$. However, the limitation of capital loss carryovers rests on ascertainable policy considerations, since the capital loss deduction is similarly restricted in the year of realization. Id. $\S 1211$. Both $\$ \$ 1211$ and 1212 serve to implement a policy of discouraging prompt loss-taking. Although some tax offset accrues as a result of the capital loss deduction, the incentive to take losses is not so great as if ordinary deductions were allowed. See U.S. Treasury DeP'T Tax Advisory Staff, Federal Incone Tax Treataient of Capital Gains and Losses (1951).

148. "In the case of an individual, there shall be allowed as a deduction all the ordinary and necessary expenses paid or incurred during the taxable year-(1) for the production or collection of income; (2) for the management, conservation, or maintenance of property held for the production of income ...." INT. REv. CoDE of 1954, \& 212. For examples of § 212-type expenses, see Maurice H. Connell, 11 CCH Tax Ct. Mem. 771 (1952) (cost of maintaining property converted to resort use deductible as either business or $\$ 212$-type expense); Edward G. Acheson, Jr., 1 CCH Tax Ct. Mem. 877 (1943) (cost of maintaining an office for the management of family trust tax deductible); Barbara S. Kirkland, $1 \mathrm{CCH}$ Tax Ct. Mem. 109 (1942) (losses of dairy farm operated for profit are deductible although nonbusiness).

Criteria for ascertaining business expenses include continuity of effort, time and energy expended, and whether the activity was an avocation, making investments or working for a salary. See S. Rose Lloyd, 32 B.T.A. 887, 891 (1935) ; Charles M. Bryan, 21 B.T.A. 364, 369 (1930) ; cf. Grier v. United States, 120 F. Supp. 395, 398 (D. Conn. 1954).

149. Int. Rev. CoDE of 1954, § 167 (a).

150. Id. $\$ 165(\mathrm{c})(2)$.

151. Deductions under $\S \S 165,167$ and 212 may be described as economic, since they must be allowed if taxable income is to be based on net rather than gross income. The term economic has been used to describe such items as tax-exempt interest, which must be included in the computation of taxable income if taxable income is to reflect net increase in economic worth. See 5 Mertens $\$ 29.02$. Applied to deductions, rather than items of income, "economic" would signify those deductions which must be allowed if taxable income is to be based on net increase in economic worth. Equating taxable income with net economic gain can never be wholly achieved, however, without abandoning the administratively necessary requirement of a "realization." See Magill, Taxable Incone 22 (rev. ed. 1945). 
A similar problem may arise if deductions were allowed in the initial taxable year for purposes other than to ensure the tax-free recovery of capital expenditures. Seeking to alleviate hardship or to encourage certain activities, Congress has granted a number of such "noneconomic" deductions. ${ }^{152}$ Because such deductions (with the exception of the one for casualty losses) are denied carryover treatment, ${ }^{153}$ seemingly unwarranted distinctions exist between taxpayers with similar deductions but different income patterns. For example, assume that $T 1, T 2$ and $T 3$ each have the same overall net income at the end of a three-year period, but that $T 1$ and $T 2$ are homeowners entitled to mortgage interest and property tax deductions unavailable to T3.154 Although all three receive the same net income, $T 3$ will have more taxable income than either of the other two. This inequality derives from a statute which favors homeowners with tax deductions. If, however, $T 1$ suffers a net loss year in which he cannot use his deductions beneficially, an inequality will also arise between him and $T 2$, since the deductions may not be carried over to other years. Thus, $T 1$ with unused deductions will occupy the same tax position as $T 3$, who never could have taken the deductions initially. In this way, the denial of carryover causes $T 1$ to be taxed more heavily than $T 2$, even though both are entitled to identical deductions and, over the three-year period, enjoy the same net income. In sum, the discrimination between $T 1$ and $T 2$ finds no basis in policy but results instead from the fortuitious irregularity in $T 1$ 's receipt of income.

Congressional hesitation to extend carryover treatment to noneconomic deductions may stem partly from apprehension that the resulting revenue loss will require generally increased tax rates. Nevertheless, deductions taken in a current year by, say, homeowners can also necessitate increased tax rates for everyone-an increase presently deemed justifiable. Since the distinction between homeowners with beneficial and those with nonbeneficial deductions involves a mere question of chance, the prohibition of carryover deductions constitutes an arbitrary limit on the extent to which Congress will employ tax relief to promote a given objective. And since the extent of tax relief available through a deduction plus carryover probably does not offer substantially greater economic incentive than that generated by the deduction alone, the omission of incentive-based deductions from carryover computation might well be sound. Otherwise, the taxes of one group, decreased for no purpose, would create revenue losses which must be restored by taxpayers generally. Nonetheless, those taxpayers who utilize carryovers have fluctuating income and thus,

152. See, e.g., INT. REv. CODE of 1954, § 213 (deduction easing medical hardship); id. $\S 214$ (deduction favoring gainfully employed mothers).

153. See id. $\S \S 172$ (d) (3)-(4), quoted note 13 supra. Since nonbusiness deductions are included in net operating loss computation only to the extent of nonbusiness gains, no excess deductions remain to be carried over.

Casualty losses are made deductible by $i d . \S 165(c)(3)$, and are given carryover effect by $i d . \S 172(\mathrm{~d})(4)(\mathrm{C})$.

154. See id. $\$ \$ 163$ (a) (interest), 164(a) (property taxes). 
under progressive rates, pay higher taxes than persons who receive the same total income evenly distributed over the years. The extension of carryovers to incentive deductions is therefore justifiable only on the ground that taxpayers who earn fluctuating income bear a tax burden that should be alleviated-even at the price of raising everyone's tax rates. On the other hand, congressional policy underlying deductions intended to relieve hardship is better achieved through deductions plus loss carryovers, for here the carryover necessarily supplements the deduction's intended function of providing tax relief.

Whether carryovers should embrace noneconomic deductions might also be answered in terms of how often the carryovers would be claimed by taxpayers who do not now report their income. For instance, the inclusion of personal exemptions in carryover computations would require millions of taxpayers presently below the reporting level to file returns. ${ }^{155}$ Since these taxpayers occupy the lowest brackets, possible individual tax benefits would not be great enough to warrant the attendant administrative inconvenience. ${ }^{156}$ No similar justification, however, supports the requirement that net operating loss be reduced by personal exemption deductions before the loss is used in any carryover year after the first. ${ }^{157}$

General denial of noneconomic-deduction carryovers is further indicated by the impossibility of reviewing a great volume of low-income returns peculiarly susceptible to padded charitable contributions and similar deductions. Hence, carryover privileges, which might encourage even greater padding than now exists, should be denied in an area where extensive auditing of returns is not worthwhile and the need for carryovers is moderate at best. On the other hand, the present inclusion of casualty losses in net operating loss indicates that some noneconomic deductions may occasion insufficient fraud to justify denying carryovers effecting congressionally favored tax relief. ${ }^{158}$

In contrast with purely noneconomic outlays, nonbusiness expenditures made for profit are likely to be undertaken by a relatively small group of taxpayers who enjoy years of large income. For them, the imposition of high rates results in oppressive taxation whenever intermittent loss years reduce total, multiannual income. Therefore, as previously indicated, ${ }^{159}$ loss carryovers should embrace deductions reflecting outlays for profit-seeking ventures.

The suggested expansion of loss carryovers in time for a fifteen or twentyyear period and in scope to include nonbusiness deductions would minimize the necessity for tax benefit relief. Only in the area of capital losses-where special limitations on deductibility reduce the effectiveness of carryovers-need the tax benefit rule be retained. Elsewhere, the rule would be superseded since, in every case in which its administration is feasible, carryover relief would be

155. See Joint Comanittee on the Economic Report, Feneral Tax Policy for EcoNomic Growtry and Stabmity, 84th Cong., 1st Sess, 136 (1955).

156. Ibid.

157. See notes 15-18 stipra and accompanying text.

158. See INT. Rev. CODE of 1954, \& 172(d) (4) (C).

159. See text at note 144 supra. 
available. The demise of the rule follows as a logical consequence. If an amount received in the present restores a loss sustained in the past, the instant receipt is a recovery of capital whether it stems from the transaction creating the loss or not. Accordingly, the ability to use the earlier loss as an offset against the later gain should not depend on a same-transaction requirement. And the elimination of that requirement converts the tax benefit rule into a carryover device permitting prior losses to offset any subsequent gain. ${ }^{160}$ The problem of computing carryover deductions for long periods of time should prove no greater than under the rule, for in both instances taxpayers must demonstrate the existence and extent of previous nonbeneficial deductions. ${ }^{161}$ Although extended carryovers would increase the degree to which the tax payable each year is dependent on the events of other years, this derogation from the precepts of annual accounting would not hinder a regular flow of revenue. The government would continue to collect annual income taxes, but the taxpayer could now ensure that only income, not capital, was taxed.

160. See text at notes 91-95 supra.

161. For a discussion of various methods of computation, see Plumb, The Tax Benefit Rule Today, 57 Hanv. L. Rev. 129, 152-55 (1943). 